\title{
衛星リモートセンシングを適用した広島豪雨災害の予測と評価 \\ Prediction and Evaluation of Earth Flow Disaster in Hiroshima \\ Using Satellite Remote Sensing
}

\author{
島 重章 ${ }^{a)}$ ・後藤恵之輔b
}

Shigenori SHIMA and Keinosuke GOTOH

\begin{abstract}
In Hiroshima there are many steep slopes. Recently, the development of the mountain slope has brought up the possibility of earth flow disaster. Therefore, the risk prediction technique has become a necessity.In this paper, the earth flow disaster, which occurred in Hiroshima on June 29,1999, was examined using artificial satellite data of wide area. The satellite information data showed the usefulness of the risk prediction technique in forecast the slope torrent of mountains. Furthermore, the accuracy confirmation of the earth flow disaster prediction technique by using the satellite data showed the effectiveness of the future application.

Key words : weathering granite, natural slope, earth flow disaster, remote sensing, risk prediction.

\section{和文要旨}

全国的にも急傾斜地の多い広島市において，近年の山簏部開発は，土砂災害の危険性をもたらしているといえる。しかしながら， その危険性を予測するための対応策は，困難を要している。ここでは，1999年 6 月29日の広島豪雨災害発生筒所を広域情報として 捉えた人工衛星データを用いて，災害発生以前のデータが示す情報の適用により，溪流斜面における風化土の堆皘情報をもとに危 険度予測手法の有用性を示した。さらに，衛星デー夕による土砂災害の規模および位置の確認が今後の評価へ有効であることを示 した。

キーワード：風化花崗岩，自然斜面，土砂災害，リモートセンシング，危険度予測
\end{abstract}

\section{1.はじめに}

日本列島は，地款変動帯に位置している。地形，地質 は複雑であり，急峻な山地に加えてモンスーン常襲地帯 に位置するため, 豪雨豪雪型の厳しい気象条件下にある といえよう。したがって，降雨災害の発生しやすい国土 構造を有していると考えられる。また, 環太平洋地震地 帯に位置しているので地震災害の発生も多い。近年，わ が国に発生した自然災害を表一 1 に示す1)。

このような災害は, 自然現象としての土砂移動現象と, 我々の生活の場が交わる時にはじめて災害の対象となる。 我々の生活をとりまく社会環境は, 生産活動の拡大に伴 い, 生活の場が平地から山地へと拡大した。そのことが, 近年の気象条件を誘因として発生する土砂災害との関わ りを多くし，市街地への土砂災害によって甚大な被害を 発生させているといえよう。

近年の土砂災害は, 国内において毎年各地で発生して いる。土砂移動現象のうち斜面崩壊は，地すべりに比べ て一般に小規模であるが，顕著な前兆を伴うことなく突 発的に発生する場合が多い。ここ 20 年間の平均発生件数 は500件／年であるが，斜面崩壊の件数はその半数以上 を占め，それに伴い人的被害も毎年多発している2)。斜

* 連絡著者/corresponding author

a) 広島工業大学工学部建設工学科

Faculty of Engineering Hiroshima Institute of Technology 下731-5193 公盘市佐伯区三宅2-1-1

2-1-1, Miyake, Saeki-ku. Hiroshima, 731-5193, Japan

b) 脣崎大学大学院生産科学研究科

Graduation School of Science and Eng. Nagasaki University

\section{表一 1 最近の我が国の自然災害}

Table 1 Natural disaster of the latest our country

\begin{tabular}{|c|c|c|}
\hline 年月日 & 災 害 名 & 主な被災地 \\
\hline H2. 11. 17〜 & 普筫岳噴火 & 島原市 \\
\hline 3. $9.12 \sim$ & 台風 $17,18,19$ 号 & 全国 \\
\hline 5.1 .15 & 釧路沖地展 & 釧路市 \\
\hline 7.12 & 北海道南西沖地震 & 北海道 \\
\hline $7.28 \sim$ & 平成 5 年 8 月豪雨 & 全国 \\
\hline 6.12 .28 & 三陸はるか沖地震 & 青森貫 \\
\hline 7. 1.17 & 阪神·淡路大地震 & 兵庫㽣 \\
\hline 8.12 .6 & 土石流 & 長野, 新潟 \\
\hline 9. 7.10 & 土石流 & 鹿罗盘出水市 \\
\hline 10. $8.26 \sim$ & 平成 10 年 8 月末豪雨 & 福帛，杤木，茨城 \\
\hline $9.21 \sim$ & 台風 18 号 & 九州 \\
\hline 11. $6.23 \sim$ & 梅雨前線毒雨 & 西日本 \\
\hline 12. 3.31 & 有珠山喷火 & 北海道 \\
\hline 12. 10.6 & 鳥取西部地震 & 鳥取，島根 \\
\hline 13. 3.24 & 芸予地震 & 広島, 要媛 \\
\hline
\end{tabular}

面崩壊は, 地質, 地形, 地盤, 地理などの多岐に渡る要 因が発生要因になると考えられる。このような要因のも とで発生する斜面災害に対して，「時刻」「「規模」「「場 所」に関する要素を明らかにすることは，地域災害の原 因を究明し, 予知・予測により避難・回避できる社会環 境を構築するために必要不可欠である。

災害の発生後に行われる緊急を要する被害状況調査と しては，従来から航空写真測量が効果を発揮している。 航空写真は太陽光のうちの可視光線を捉えて可視化した ものである。さらに地盤調查を行うには，太陽光が示す 可視光線デー夕に加えて, それより波長の長い赤外線 データが有効であると考えられる。それは地表面の熱量, 
蒸発散量および水分量を感知するためである。斜面崩壊 のような土砂災害を事前に予測するためには，地盤調査 データが必要不可欠になると考えられる。リモートセン シング技術は，可視域から赤外域までのデー夕を用いた 特徵抽出が可能であり，地表面を構成する物質を分類す ることが可能である。

危険箇所の予測のための調查を検討していくために, 表層地盤に対する地域性，経年性，周期性を対象とする デー夕を用いて，筆者らはこれまでに衛星リモートセン シングによる地盤工学への適用性を検討してきた ${ }^{3445)}$ 。

本論文では，1999年 6 月29日に発生した広島豪雨災害 の発生原因を明らかにするために，国産地球観測衛星に よって得られた災害発生以前のリモートセンシングデー 夕をもとに，これまでの既報をとりまとめて斜面崩壊発 生の予測と評価を行うものである。

\section{2. 風化花崗岩地域の地域特性と災害履歴}

\section{1 地域特性}

集中豪雨を誘因とする土砂災害は，地盤表層の脆弱箇 所に現れ，土砂移動現象になると考えられる。西日本を 広く覆う花崗岩地带では，風化層の中に脆弱箇所を見出 すことができる。従って，このような地域では，集中豪 雨による斜面崩壊やがけ崩れなどの土砂災害の多いこと も古くからよく知られている。

ここでは，広島豪雨災害が発生した広島型風化花崗岩 地域の特性を述べる。対象とする範囲は，広島県の西部 に位置して，図- 1 に示す 5 万分の 1 地形図N 5-53-33 -10「広島」である。地勢は, 広島湾に面する広島平野, その背後の丘陵地や中国山地などが主な地形である。広 島平野は，中国山地に源を発する太田川の流下によって 三角州を形成し，市街地を発展させた。その周辺は，標 高300 500mの山地で取り囲まれ，比較的ゆるやかな傾 斜の山地部が広がっている。特に対象とする西部域は, 佐伯区から隣接の廿日市市にかけて700m前後の山地に 囲まれ，その山地部が前面の広島湾に急傾斜で臨んでい

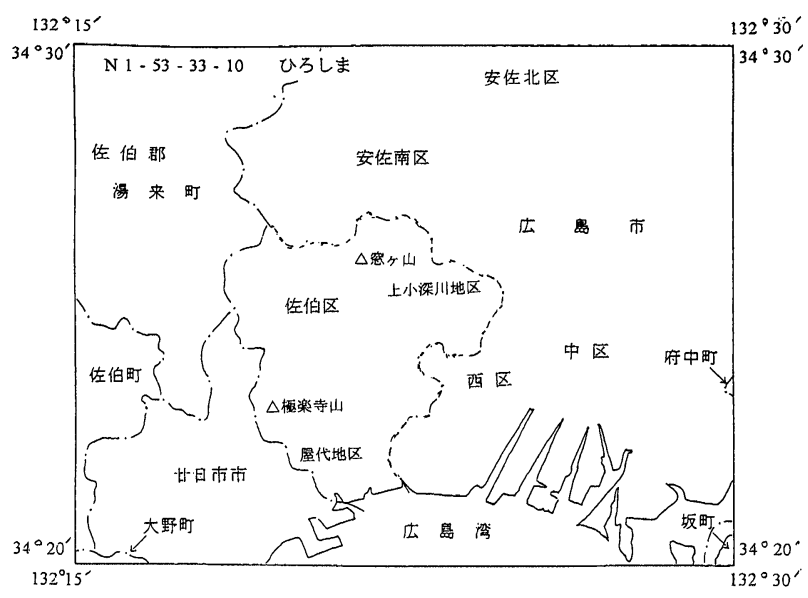

図-1 対象地域の位置概略図

Fig. 1 Outline map of the object area
る。広島市およびその周辺は，平坦地が少ないという地 形上の制約があり，古くから海面の埋め立てが進められ てきたものの，近年では，市街地が周辺の山地および丘 陵地に拡大しているあ。

(1) 地形

対象地域の広島市佐伯区周辺は，瀬戸内海からわずか な平地の広がりと谷地形を示し，全体的に標高500～600 $\mathrm{m}$ 程度の山地部から構成される。この地域は, 中生代白 亜紀の造山運動により形成された地形を成し，隆起準平 原化した山体が，侵食堆積を繰り返して現在の地形を形 成した。

(2) 地質

この地域の地質は, 白亜紀後期の広島花崗岩類を母体 とする山体および第四紀層の堆積物から構成される。広 島花崗岩類は，黒雲母花崗岩拉よび角閃石花崗岩を主と する。第四紀層は，主に平地部に分布している沖積層の ほか, 山間部の極楽寺砂層, 段丘堆積物, 崩壊堆積物か らなる。この地域の山地は，地盤特性として深層風化層 を伴い，表層は風化残積土および風化崩積土であるまさ 土によって覆われているのが特徵的である。

(3) 土地利用

広島市の周辺では，太田川をはじめ，安川，吉山川， 伏谷川, 可愛川, 御手洗川, 八幡川, 三筋川およびその 支流流域の低平地に打いて水田を主とする農業が行われ てきた。また，山林は，大きく分けて南東部の大半を占 める人工針葉樹林地域, 北西部の一隅を占める広葉樹林 地域，および中間にあるアカマツ林を含む混交林移行带 の 3 地域に分けることができる。

(4) 傾斜

広島市は，陸地部分のうち山地が約 7 割を占め，国内 で最も急傾斜地の多い地域としてあげられる。したがっ て低地部の少ないこの地域は，山地部の開発が近年急速 に拡大した。

山地部は，西に行くに従い高度と起伏を増し，それに 応じて急傾斜の地域が広くなっている。山地のうち傾斜 $30^{\circ}$ 未満の傾斜分布を見ると, 北東一南西方向の地形配 列に沿って伸びる傾向がある。調查対象地域は，土砂災 害の発生した屋代川地区の極楽寺山山簏が $15^{\circ}$ 以上 $20^{\circ}$ 未 満, 上小深川地区の窓ヶ山山麓が $8^{\circ}$ 以上 $15^{\circ}$ 未満の傾斜 を示している7。

\section{2 広島豪雨災害の被災状況}

対象とした調查地域は, 北緯 $34^{\circ} 22^{\prime}$, 東経 $132^{\circ} 25^{\prime}$ を 中心位置とする広島市佐伯区の山地部の土砂崩壊現場で ある。1999年 6 月 29 日未明から降り続いた雨は, 午後 3 時以降に集中豪雨となり，広島市西部から北部にかけて $60 \mathrm{~mm} / \mathrm{hr}$ 前後の降雨をもたらした。広島市西部域にお ける観測資料を図ー 2 に示す8)。この降雨は局所性が強 く，広島市内ではあまり降雨が無いにもかかわらず，当 該地では最大 2 時間降雨量が60〜80 mmを記録してい る9)。この集中豪雨により同地域において山腹の崩壊が 


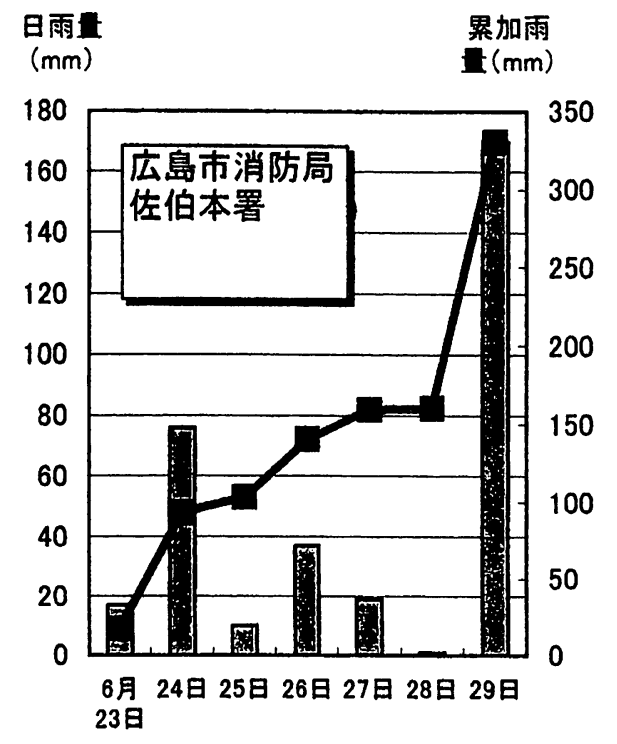

図一 2 (a) 降雨量の日変化（広島市消防局提供）

Fig. 2 (a) Change of precipitation of rainfall (Offer of Hiroshima fire-fighting office)

\section{表一 2 広島豪雨災害による被害状況}

Table 2 Damage situation by the Hiroshima heavy rain calamity

\begin{tabular}{|c|c|c|c|c|c|c|c|c|c|c|c|c|c|c|c|c|}
\hline & \multicolumn{5}{|c|}{ 厷島全体 } & \multicolumn{5}{|c|}{ 広島市域 } & \multicolumn{6}{|c|}{ 甚市域 } \\
\hline & \multirow{2}{*}{ 件数 } & \multicolumn{2}{|c|}{ 人的被害 } & \multicolumn{2}{|c|}{ 家屋の被害 } & \multirow{2}{*}{ 件数 } & \multicolumn{2}{|c|}{ 人的被害 } & \multicolumn{3}{|c|}{ 家屋の被菑 } & & \multicolumn{2}{|c|}{ 人的被宣 } & \multicolumn{2}{|c|}{ 家幄の被壱 } \\
\hline & & 死者 & 負灀 & 全嫃 & 半境 & & 死者 & 目偖 & 全 & 半 & & & 死者 & 負僄 & 全塹 & 半榱 \\
\hline $\begin{array}{c}\text { 土石流 } \\
\text { 等 }\end{array}$ & 139 & 13 & 5 & 49 & 62 & 107 & 13 & 5 & 4 & 6 & & 10 & - & - & - & - \\
\hline $\begin{array}{c}\text { 地すべ } \\
\text { り }\end{array}$ & - & - & - & - & - & - & - & - & - & . & & - & - & - & - & - \\
\hline $\begin{array}{c}\text { がけ崩 } \\
\text { れ }\end{array}$ & 186 & 11 & 9 & 15 & 12 & 46 & 4 & 3 & 7 & 3 & & 115 & 6 & 3 & 7 & 9 \\
\hline 合部 & 325 & 24 & 14 & 64 & 74 & 153 & 17 & 8 & 5 & 6 & & 125 & 6 & 3 & 7 & 9 \\
\hline
\end{tabular}

各所に発生した。特に花崗岩の風化土により構成された 地盤表層は，風化の進行した急傾斜地の山腹崩壊を促進 させ，土石流となって数キロの溪流を流下して下流の田 畑や家屋を直撃し, 都市化の進行した団地への土砂流入 を各地区で発生させた。主な災害状況を表一2に示す ${ }^{10)}$ 。

\section{3. 衛星リモートセンシングデータの適用}

\section{1 人工衛星データの概要}

自然現象を調査・解析する際に重要なことは，広域を 見渡すこと，多くの側面から現象を見ることである。ま ず最初の視点は，人工衛星りモートセンシングによって， 人間は宇宙から広域を観察することを可能とした。技術 の進歩によって，この宇宙からの観測精度は年々高まる 傾向にある。次の視点は, 地理情報システムの登場によっ て数多くの情報を扱うことのできる，優れた電子頭脳を 入手することを可能にした。人間の判断を加えることに より多現象の解析が可能となったのである。

リモートセンシング衛星データは, 光学センサーとマ

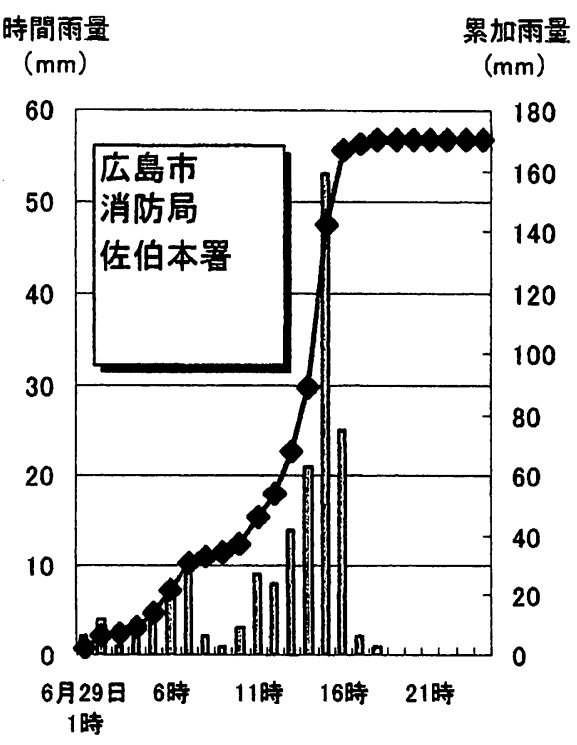

図一 2 (b) 時間降雨量変化（広島市消防局提供）

Fig. 2(b) Time precipitation chang of rainfall (Offer of $\mathrm{Hi}-$ roshima fire-fighting office)

イクロ波センサーに大別される。ここでは，地球表面の 物質の分光反射率が異なることを利用した光学センサー データについて説明する。人工衛星が地球へ送信してく る観測情報は，反射光に対応したディジタルデータを反 射波長デー夕として提供する。このような反射波とは太 陽光の電磁波であり，その波長の範囲はおおよそ0.4〜 数 $\mu \mathrm{m}$ 程度である。光学センサーは，これらの光を波長 として捉え, 地表物質の違いを色の違いとしてデー夕処 理することで画像表示が可能となる11)。

物体の分光反射率は, 物体の種類によって異なる。物 体からの分光放射輝度は, 分光反射率の影響を受けてい るため, 数 $100 \mathrm{~km} の$ 遠方からでも物体を識別できるので ある。その例を紹介すると，まず土地被覆の代表的デー 夕として植物，土，水の分光反射率を図－3に示す。植 物は近赤外の領域で強い反射率を示し，土は可視領域と 中間赤外で反射率が強く，水は全体的に反射率が小さい。 植物が示す緑色は，針葉樹と広葉樹が同じ緑色をしてい

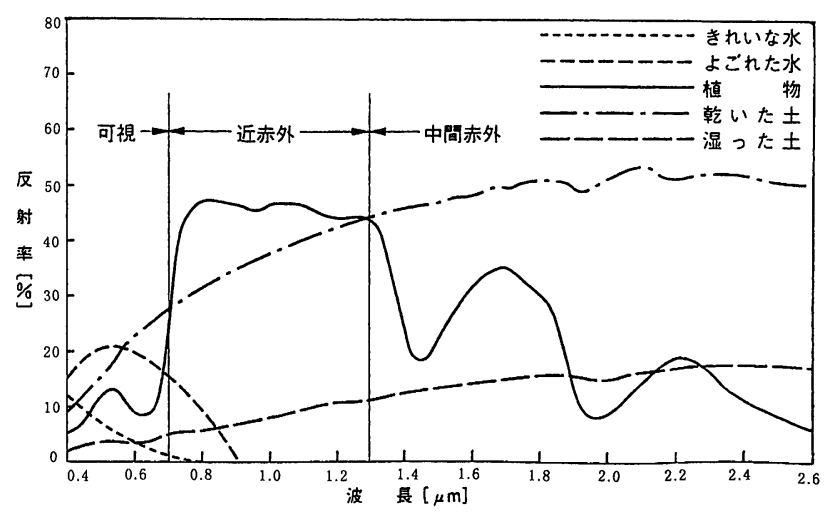

図一 3 植物, 土, 水の分光反射特性

Fig. 3 Spectrum reflectance of a plant, ground, and water 


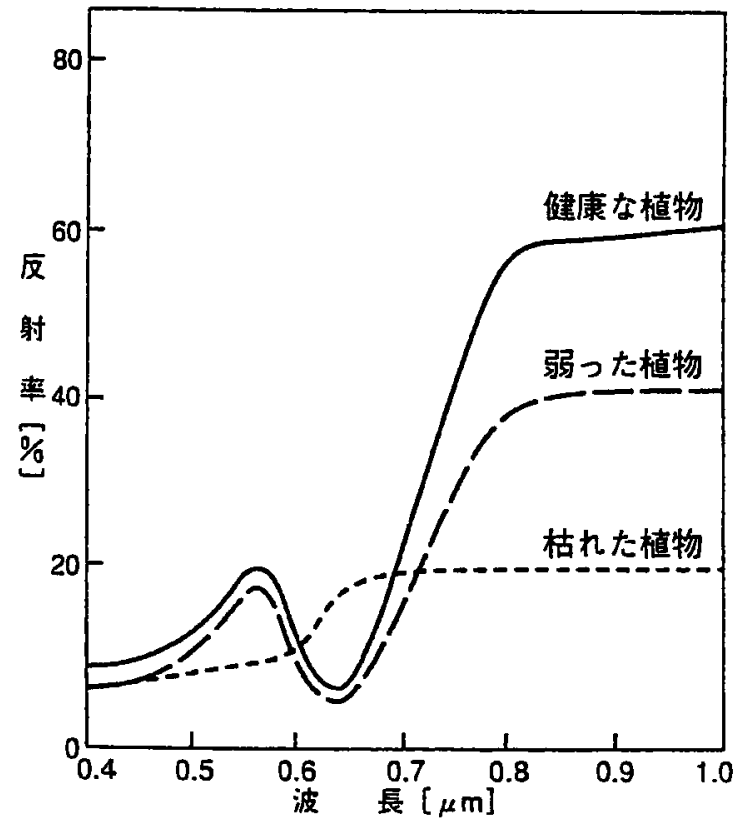

図ー4 植物の分光反射率

Fig. 4 Reflectance of vegatation spectrum

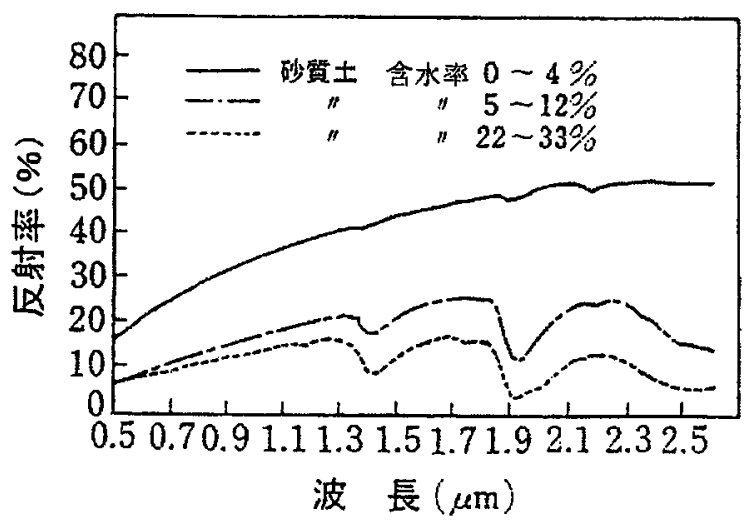

図－5 地篮表面の分光反射率

Fig. 5 Reflectance of spectrum on the ground surface

ても実際には違う緑色である。さらに近赤外域における 大きな違いは，葉の細胞構造の違いにあるといわれてい る。その一例を図ー 4 に示す。また，岩石や土も種類に よって反射の特性が異なっている。図－ 5 は，地盤表面 の反射特性を示している。可視域から赤外域になるに従 い反射率の変化は大きくなる。これらは土の種類と共に 密度および含水量の多少が大きく影響している ${ }^{12)}$

したがって，センサーによって捉えられる0.75 $\mu \mathrm{m}$ 以 上の赤外域のデータは, 水分の蒸発散量や, 放熱量に依 存した对象物からの放射デー夕を示すことになる。その 代表例が正規化差分植生指標（NDVI）であるが，同様 に地形，地質，水分などの情報の抽出が可能になると考 えられる。

ここに使用した人工衛星データは，地球観測プラット フォーム技術衛星みどり（ADEOS）である。この衛星 は, 地球温暖化, 熱帯雨林の減少, 異常気象の発生等の 環境変化に対応した全地球規模の観測デー夕を取得し,
表ー 3 搭載センサ

Table 3 Satellite sensor

\begin{tabular}{|l|c|c|c|l|}
\hline センサ名 & バンド & 波長範囲 $(\mu \mathrm{m})$ & 区分 & 分解能 \\
\hline 高性能可視 & BAND 1 & $0.42 \sim 0.50$ & B (青系) & $16 \mathrm{~m}$ \\
近赤外放射 & BAND 2 & $0.52 \sim 0.60$ & G(緑系) & $16 \mathrm{~m}$ \\
棓 & BAND 3 & $0.61 \sim 0.69$ & R(赤系) & $16 \mathrm{~m}$ \\
(AVNIR) & BAND 4 & $0.76 \sim 0.89$ & 近赤外 & $16 \mathrm{~m}$ \\
\hline
\end{tabular}
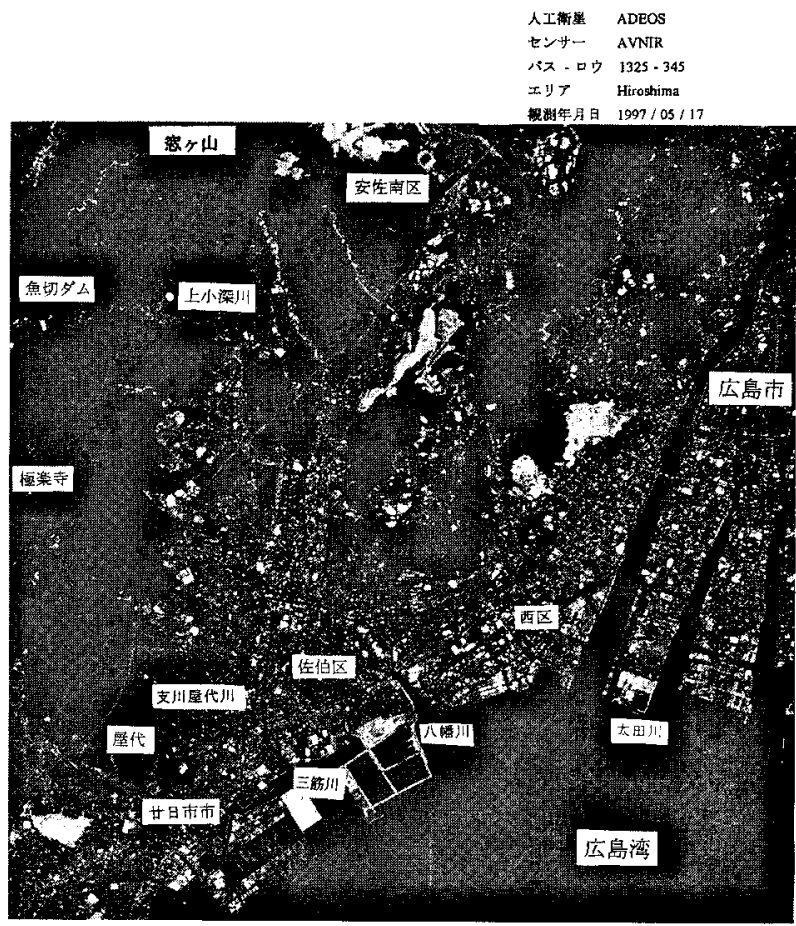

図ー6 人工衛星データ ADEOS/AVNIRデータによる調査 対象地域

Fig. 6 Investigation region by ADEOS/AVNIR satellite data

国際協力による地球環境監視に役立てると共に，次世代 地球観測プラットフォーム技術の開発を目的とした衛星 である。この衛星には陸域，海域，大気を総合的かつ継 続的に観測するために，宇宙開発事業団（NASDA）が 開発した高性能可視近赤外放射計 (AVNIR) ほか 6 種 類のセンサーが搭載され， $\mathrm{H}$ - II 4 号ロケットにより 1996年 8 月に種子島から打ち上げられた。使用した ADEOS/AVNIRデータの中からセンサー特性を表ー 3 に，対象地域の崩壊発生以前の画像を図ー6に示した。

\section{2 使用したデータの解析方法}

災害の発生には誘因と素因があり，それらが二つ以上 作用したときに発生するといわれている。なかでも素因 を発生以前に予測することができれば，災害の軽隇に対 処できると考えられる。そのような素因には，私たちの 眼に直接感知できるものとそうでないものがある。感知 できないものとは，各種物質が有する放熱量や水分量の 違いである。このような量を計測し表現するには,リモー トセンシング技術の中で得られる波長別デー夕を用いた 特徴抽出法が有効であろう。 


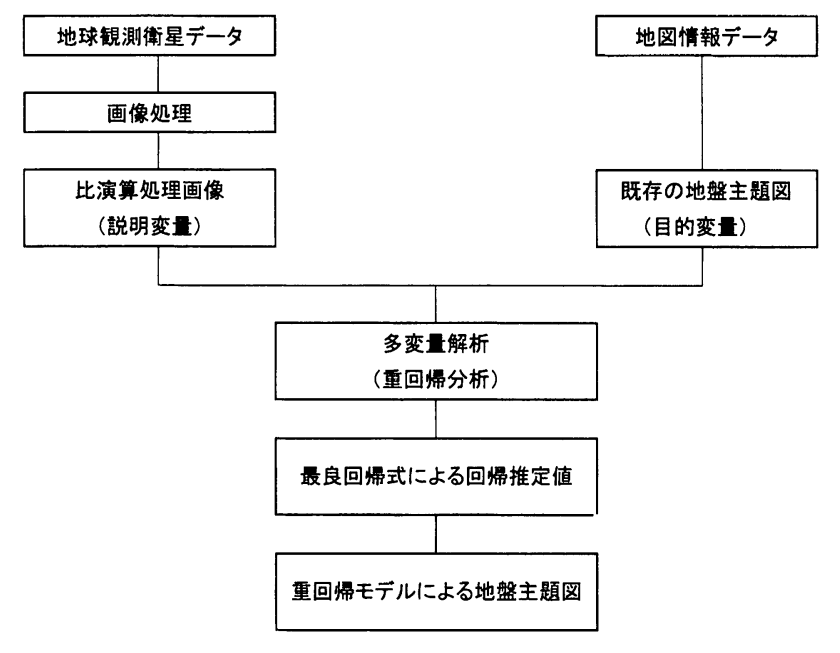

図ー7 重回帰モデル作成の流れ

Fig. 7 Flow of creation for multi regression analysis model

まず，人工衛星データが有する波長別データの利用は, 地表面に存在する事象の空間分布を表現するために，多 数の事象との相関関係を分析することが必須事項となる。 ここでは，このような空間情報の解析に重回帰分析を取 り上げた。図ー 7 に示すように, 既存抽出データとして の地盤主題図および特徴抽出データとしての比演算処理 画像を用い, 目的変量と説明変量との設定による重回帰 分析を適用した。段階的手法をもとに得られた最良回州 式から，重回帰モデルによる新たな地盤主題図を作成す るものである。このようにして作成された地盤主題図は, 経年変化に伴い発生する既存データの問題点を解消し, 人工衛星データが捉える広域情報をもとに更新すること が可能である。ここに特徴抽出データとして用いた説明 変量は, 表 -4 に示す比演算の組み合わせによる。その 組み合わせは,

$\mathrm{Xn}=$ Ratio $-\mathrm{mn}$

であり，その演算式は,

Ratio $-m n=($ BANDm - BANDn $) /($ BANDm

+ BANDn)

\section{表 -4 変数の比演算組み合わせ表}

Table 4 Operation combination table of the ratio of a variable

\begin{tabular}{|cc|c|c|c|c|}
\hline & $\mathrm{n}$ & $\mathrm{BAND}$ & $\mathrm{BAND}$ & $\mathrm{BAND}$ & $\mathrm{BAND}$ \\
$\mathrm{m}$ & 1 & 2 & 3 & 4 \\
\hline BAN D & & $\mathrm{X} 1$ & $\mathrm{X} 2$ & $\mathrm{X} 3$ \\
$\mathrm{BAND}$ & 2 & $\mathrm{X} 4$ & & $\mathrm{X} 5$ & $\mathrm{X} 6$ \\
$\mathrm{BAND}$ & 3 & $\mathrm{X} 7$ & $\mathrm{X} 8$ & & $\mathrm{X} 9$ \\
$\mathrm{BAND}$ & 4 & $\mathrm{X} 10$ & $\mathrm{X} 11$ & $\mathrm{X} 12$ & \\
\hline
\end{tabular}

$\mathrm{Xn}=$ Ratio $-\mathrm{mn}$

Ratio $-\mathrm{mn}=(\mathrm{BANDm}-\mathrm{BANDn}) /(\mathrm{BANDm}+\mathrm{BANDn})$
表ー5 重回帰モデル式

Table 5 Multi regression model formula

\begin{tabular}{|c|c|c|}
\hline 作成项目 & 息回鲳モデルによる最良回淿式 & 奇与事 \\
\hline 土地利用区分 & $\mathrm{Y}=-0.616 \mathrm{X}_{2}+0.272 \mathrm{X}_{5}-0.178 \mathrm{X}_{10}+65.848$ & 0.781 \\
\hline 表層地䓄区分 & $Y=-3.161 X_{1}-2.925 X_{2}-2.075 X_{7}-3.368 X_{10}+4.071 X_{11}+564.429$ & 0.894 \\
\hline 地形区分 & $Y=0.234 X_{2}+0.054 X_{6}-78.58 s$ & 0.711 \\
\hline 風化度区分 & $Y=3.676 X_{2}-0.834 X_{3}+0.966 X_{6}+3.423 X_{7}-911.403$ & 0.894 \\
\hline 頃科区分 & $Y=2.685 X_{3}+2.964 X_{6}+2.793 X_{7}-3.011 X_{10}-0.055 X_{11}+72.234$ & 0.921 \\
\hline 蚫和度区分 & $Y=-0.721 X_{2}-0.407 X_{10}+0.535 X_{12}+136.672$ & 0.964 \\
\hline 土填区分 & $Y=0.792 X_{6}+0.342 X_{8}+0.632 X_{11}-132.067$ & 0.842 \\
\hline
\end{tabular}

である。

\section{3 地盤災害関連情報データの適用}

対象とする地域の斜面崩壊は，極楽寺山（標高 $661 \mathrm{~m}$ ) を発端とする屋代川の急斜面を流下し，土石流災害を発 生させて人的，物的に多大なる被害をもたらした。この 五日市地域は，人口 12 万人の地区を構成し，近年，広島 市の衛星都市として山麓の開発と共に都市化が発達して きた地域である。図ー 6 に示した画像は，1997年 5 月 17 日観測の空間情報データである。このようなデー夕を用 いて地表面の状況を解明するには, 多数個の事象との相 関関係を検討することが必要である。ここでは，多変量 解析の中から空間相関分析として用いられる重回帰分析 を取上げ，重回帰モデルの作成を行った ${ }^{13)}$ 。その適用例 を以下に示す。

同地域の重回帰モデルを作成するにあたり，ここでは 土地分類基本調査図として作成された 5 種類の主題図 （土地利用区分, 表層地質区分, 地形区分, 傾斜区分, 土壤区分 $)^{6)}$ ，および衛星デー夕の特徴抽出法により作成 した 2 種類の主題図（風化区分, 飽和度区分）をもとに, 重回帰モデル画像を作成した。結果としての重回帰モデ ル式を表ー 5 に示す。その中から，ここでは斜面災害の 関連データとして風化区分を取上げた。この風化が，当 該地域の地盤災害に大きく関わってきた要因データとし て，その特性を以下に述べる。

（1）風化度指標

風化区分のための指標は, 表層地質区分図の中に記載 の一般的な風化度指標として，地質学的に用いられてい る風化款の深度 $(\alpha \leqq 3 \mathrm{~m}, \beta \leqq 10 \mathrm{~m}, \gamma>10 \mathrm{~m})$ を基準と した。

（2）風化区分の作成精度について

人工衛星データが取得した観測マルチバンドデータが 示す単バンドデータから作成した比演算処理データを説 明変量とし, 既存データの中から目的変量を風化款の深 度とする重回帰分析を行った。その結果, 表一 6 に示す $\mathrm{F}$ 検定, $\mathrm{t}$ 検定の結果のように, 有意性の高い最良回帰 式を得た。この式をもとに，新たな地盤主題図を作成し 図ー8に示した。

以上の手法により作成した画像は, 広域の平面情報 データを示す風化区分データである。風化度を示す指標 は, 図示のように弱風化 $\alpha$ 青系 $\langle\mathrm{DN}=0 \sim 100\rangle$, 中風 化 $\beta$ を緑系 $(\mathrm{DN}=100 \sim 160)$ ，強風化 $\gamma$ 赤系 $(\mathrm{DN}=160$ 〜255）に区分し画像化した。 
表一 6 重回帰分析の結果

Table 6 Result of multi regression analysis

\begin{tabular}{|c|c|c|c|c|c|}
\hline 説明変 $(\mathrm{R})$ & \multicolumn{5}{|c|}{ 比演算処理によって得られた誧星 DN データ } \\
\hline 目的变量 $(Y)$ & \multicolumn{5}{|c|}{ 裹田地笛图から得た風化度指模 $(\alpha, \beta, \gamma)$} \\
\hline \multirow{2}{*}{$\begin{array}{c}\text { 圧縮变換 } \\
\text { Atan }\end{array}$} & \multicolumn{4}{|c|}{ 钼明变贯 } & 重相関係数 \\
\hline & $\begin{array}{c}(X 2) \\
R-13\end{array}$ & $\begin{array}{c}(X 3) \\
R-14\end{array}$ & $\begin{array}{c}(X 6) \\
R-24\end{array}$ & $\begin{array}{c}(x 7) \\
R-31\end{array}$ & $\begin{array}{c}\langle\mathrm{R}\rangle \\
0.944\end{array}$ \\
\hline F值 & F検定 & 説明变量 $(x)$ & 编回㷌保数 & \multicolumn{2}{|c|}{$\mathrm{t}$ 挨定 } \\
\hline $\begin{array}{c}F(5,7,1, \%) \\
=4.336 \\
<(17.927)\end{array}$ & 1\%有意 & $\begin{array}{l}R-13 \\
R-14 \\
R-24 \\
R-31 \\
\text { 定 数 }\end{array}$ & $\begin{array}{c}+3.676 \\
-0.834 \\
+0.966 \\
+3.423 \\
-911.403\end{array}$ & & $\begin{array}{l}\text { 有意 } \\
\text { 有意 } \\
\text { 意 } \\
\text { 意 }\end{array}$ \\
\hline \multicolumn{6}{|c|}{ 泉回棉式 } \\
\hline \multicolumn{6}{|c|}{$Y=3.676 X_{2}-0.834 X_{3}+0.966 X_{6}+3.423 X_{1}-911.403$} \\
\hline
\end{tabular}

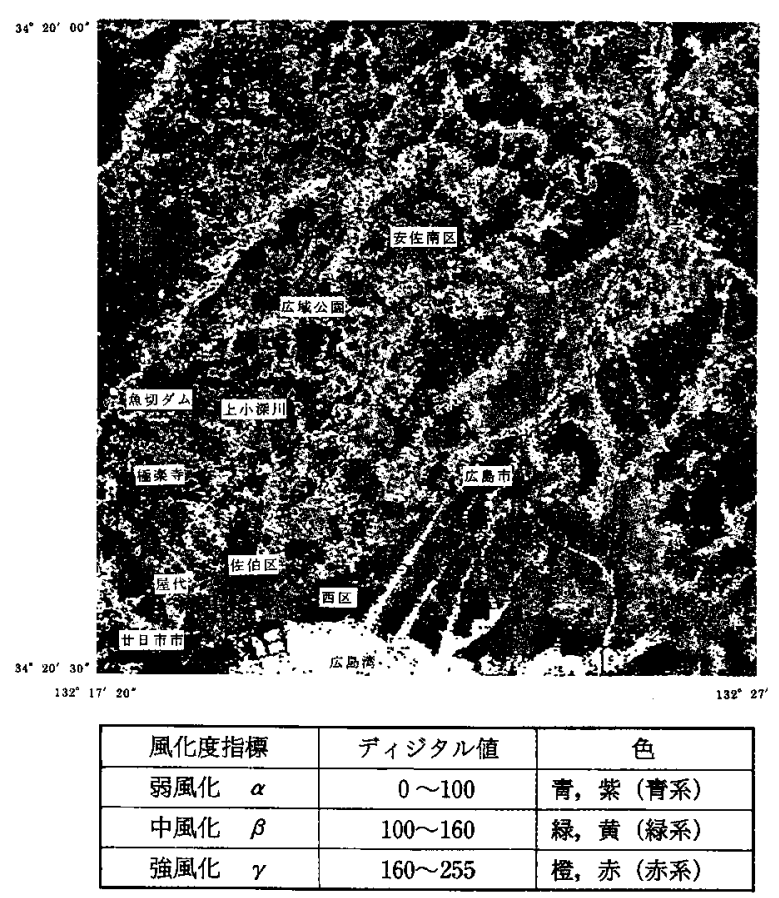

図ー8 衛星データを基に作成した風化区分図

Fig. 8 Weathering classification image created based on satellite data

（3）重回帰モデルとしての地盤主題図

地形情報を表現する場合，地図情報では以前から等高 線が利用されてきたが，近年のディジタルマッピングと してリモートセンシングデータの利用は更なる適用範囲 を広めた。重回帰モデルとして作成した地盤主題図は， 既存の主題図を更新した地理情報システムとしての利用 が可能である。例えば縮尺 1 万分の 1 画像として作成し た地盤主題図は，地盤データベース化を行うことにより 平面情報を提供する各種分野への利用が可能になる。

図-8は，対象地域における風化区分を示した画像で ある。当該地域は風化花崗岩を母岩とするまさ土に覆わ れ，山地部は急傾斜を成している。なお，ここに述べる 風化土とは, 花崗岩の風化土のうち残積土および崩積土
表一 7 風化度指標区分

Table 7 Degree index classification of weathering granite

\begin{tabular}{|c|c|c|c|}
\hline 風化度指标 & 瓜化殶哚度 & DN䛧 & 画像の色 \\
\hline 弱風化 & $3 \mathrm{~m}$ 未涌 & $0 \sim 100$ & 背色系（紫，青) \\
\hline 中風化 & $3 \sim 10 \mathrm{~m}$ & $100 \sim 160$ & 渌色采（緑，黄) \\
\hline 傺風化 & 10 m以上 & $160 \sim 255$ & 赤色系 (橙，赤) \\
\hline
\end{tabular}

の両方を指している。その谷部から平地部は，深層まで 風化の影響を受けたまさ土によって構成されている。こ の地域の地盤風化特性は, 表 -7 に示方風化度指標に 3 区分される。弱風化の地域は露出岩の多く見られる山体 に多く，風化残積土砂量も少ない。中風化の地域は一般 に地域全域に見られる風化残積土である。強風化の地域 は広島型風化花崗岩地域において風化残積土および崩積 土として存在し，低地部や谷部に多く見られる。特に広 島市周辺の標高100〜 300 m程度の丘陵山地は, そのかな りの部分がまさ土であり, 厚さ $10 \mathrm{~m}$ 以上の土砂化した層 によって構成された深層風化層を形成している。

衛星データが示す風化度の判読精度は, 搭載センサー によって瞬間視野角が示す画素単位で示される。ここで は人工衛星のセンサーが示す地表距離換算值として 1 画 素が $16 \mathrm{~m} \times 16 \mathrm{~m}$ を示すことから，ここでは地表平面距離 $16 \mathrm{~m}$ ごとのデータ判読を可能とした。

\section{4. 広島豪雨災害予測の結果と考察}

\section{1 土砂災害危険度予測への適用}

土砂災害を予測する方法としては, 各機関で多くの案 が出されている。その予测項目としては，「時刻」，「規 模」,「場所」の 3 項目の情報を得ることができれば，今 後の対策に有効であると考えられている 刻」については，基準雨量設定法等に見られるように， 降雨を誘因とする発生予測の検討が多くなされているこ

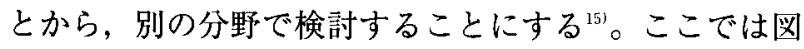
- 9 に示すように，(1)崩壊の規模および(2)崩壊の位置の 2 項目について，衛星りモートセンシングを適用した検 討を試みた。前項で述べた地盤主題図をもとに，災害の 予測のための要因を設定し, それぞれの適用について述 ベる。

\section{(1) 崩壊規模の予测}

土砂災害は，地山を構成する地質の影響を受け，土砂 移動現象を発生させ，崩壊に至る。広島周辺に発生した 土砂災害は，山体の風化が大きく影響し，各所に崩壊の 痕跡を残した。したがって，風化に伴う崩壊の予測を検 討することが必要になる ${ }^{16)} 。$

まず「規模」についての予測手法を検討する。降雨量 と移動可能土砂量から土石流の規模を推定する方法があ るが,ここでは渓流斜面における堆積土砂量をりモ一ト センシング衛星データから計測推定し，災害の規模を予 测するものである ${ }^{17}$ 。そのための適用箇所として，広島 市佐伯区において1999年 6 月29日に発生した土石流災害 を取上げた。屋代川流路に堆積したまさ土の風化崩積土 


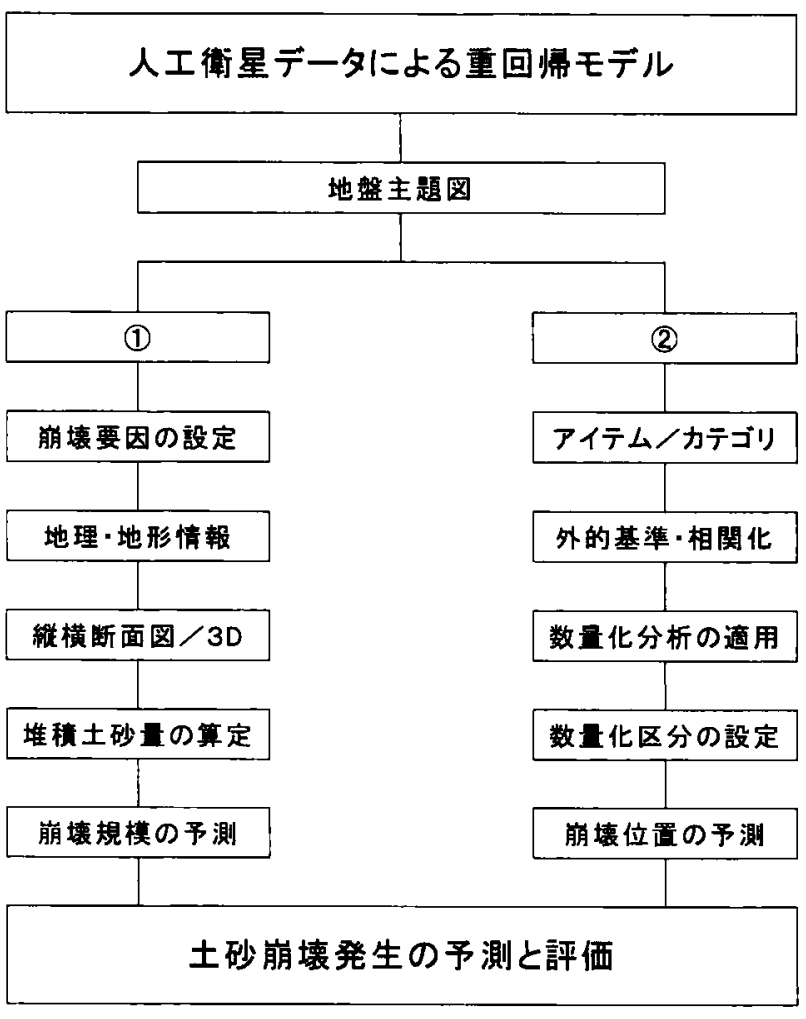

図一土砂崩壤発生の予測の流九

Fig. 9 Flow of generating factor prediction of earth flow disaster
砂量を推測するために，災害発生以前に観測したリモー トセンシングデータを用いて計測し，実際に発生した崩 壊土砂量と比較検討した。

災害の規模を推測するためのデータとして，図ー10に 土砂災害の発生した地域を拡大図示し, 図ー11に屋代川 流路の縦断面図を示し, 堆積士砂標準断面図を図一 12 に 示す。屋代川は三筋川の支川で, 約 $2,500 \mathrm{~m}$ の延長を有 する急傾斜の山地河川である。この流域の表土はまさ土 から成り, 山地斜面の植生は上流部が混交林, 中流が人 工針葉樹林によって覆われ，中下流部が自動車道路およ び団地などの生活基盤によって構成されている。この流 路において広島豪雨災害のうち最も延長の長い土石流が 発生し，流下した土砂が都市化の進行した中下流域にお いて生命および財産に多大な損害を与えた。このことか らも, 渓流斜面に堆積している土砂量を事前に流域ごと に測定できれば，被害を最小限に抑制することができる と考えられる。

ここでは, リモートセンシングデータの中から, 風化 区分画像を用いて流水路のディジタル值（以下DN值と 称す）を判読し，風化の深さを示す風化度指標をもとに 堆積土砂量へ換算するものである。このリモートセンシ ングデータが示す放射量とは, 地盤材料固有の水分量や 放射量のことであり，人間の眼に感知できない特性を示 す。したがって，空間情報量として画素単位で捉えた特 徴抽出データは，地盤情報データとしての画像表示が可

䐜化区分油像

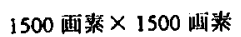

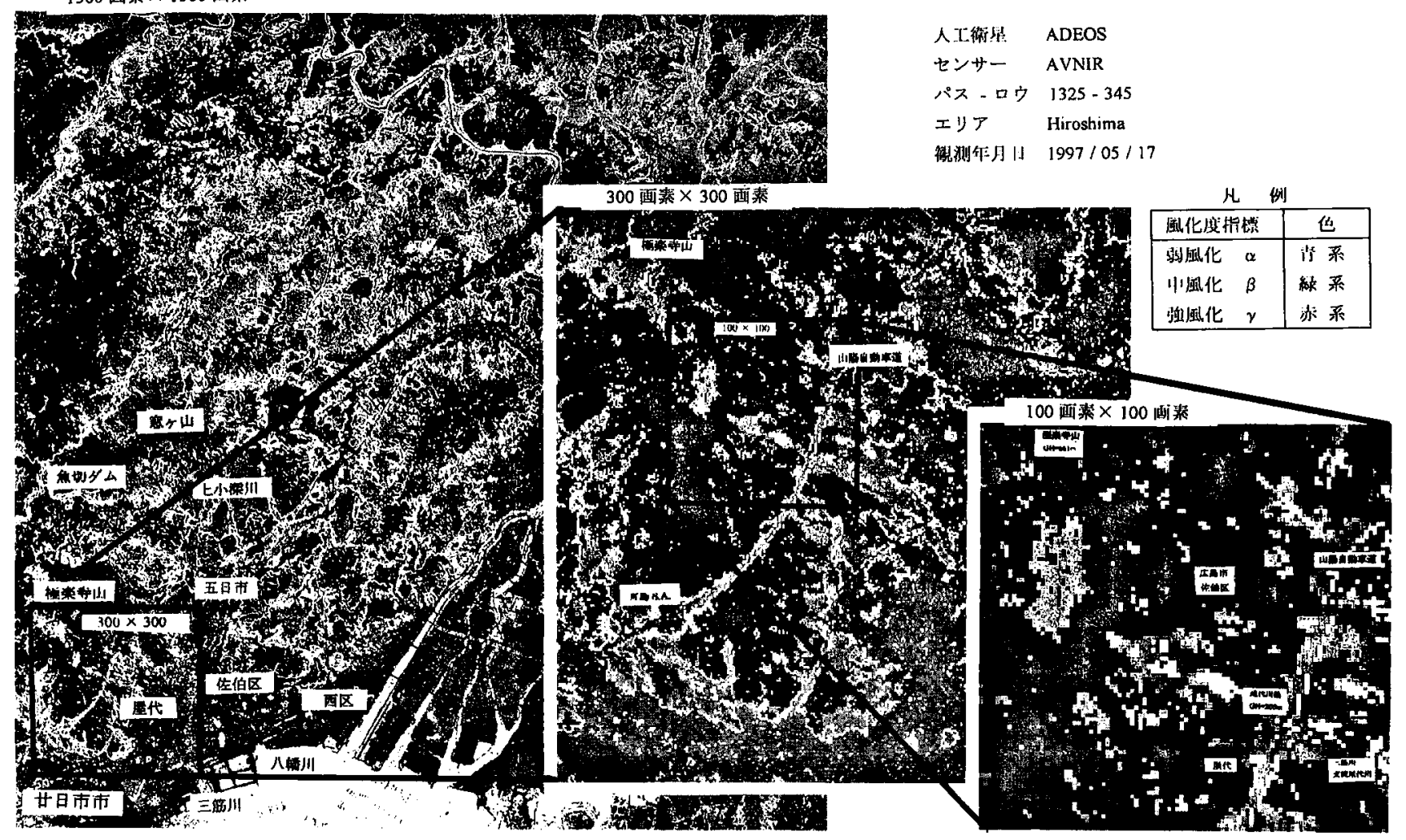

図-10 災害発生地の拡大図

Fig. 10 Enlargement of earth flow disaster area 


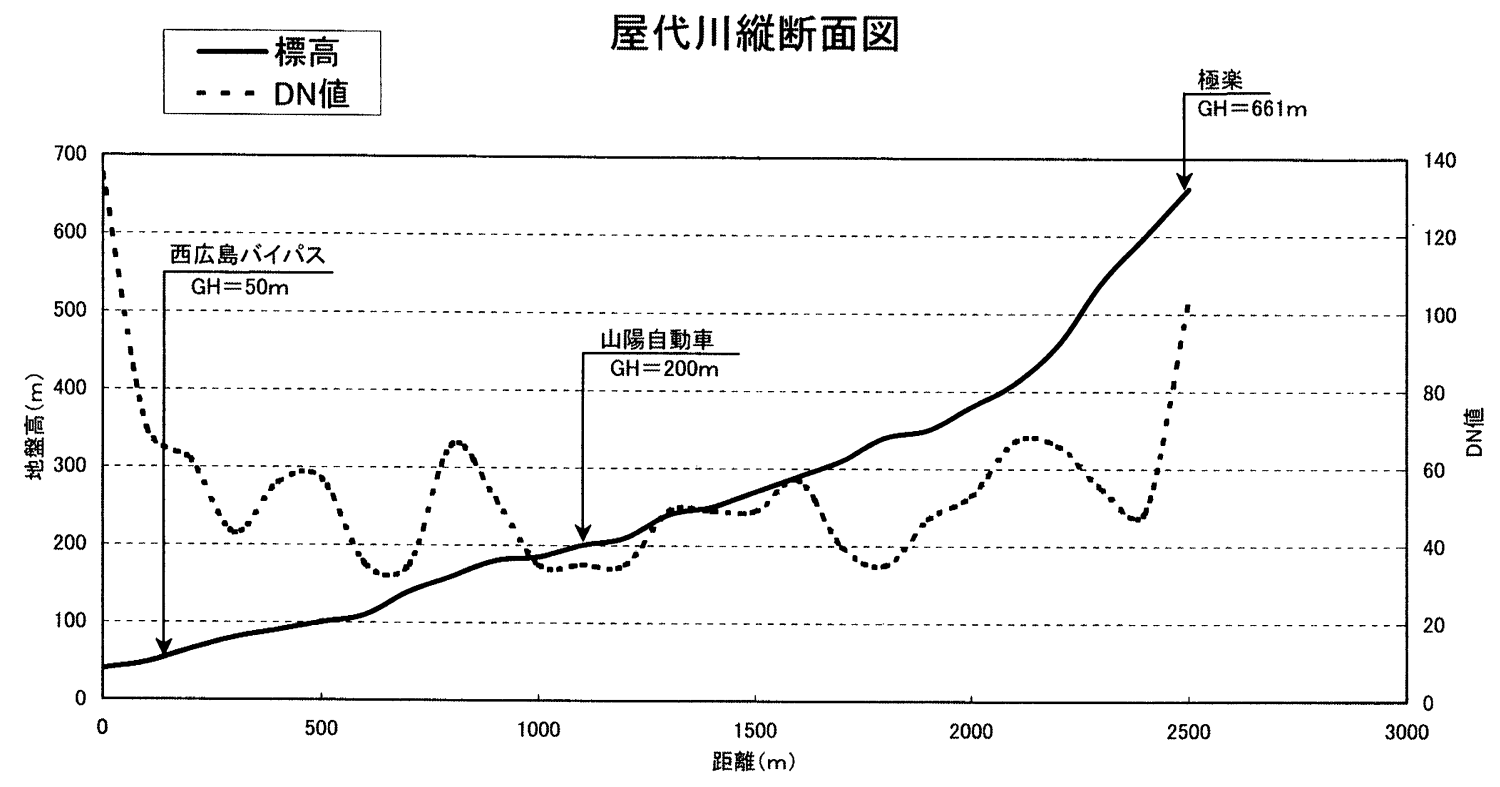

図一11対象地の縦断面図

Fig. 11 Longitudinal section of the object ground

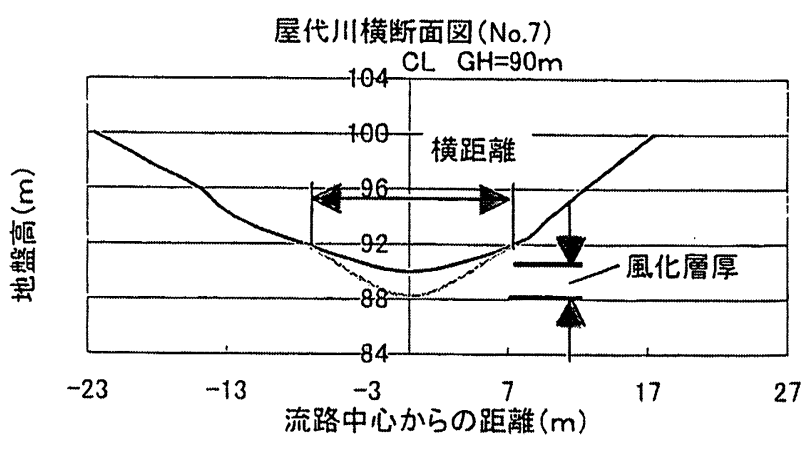

図一12 標準横断面図

Fig. 12 Standard transverse cross section

能であると考えた。対象地域の風化度は, 地形要因デー 夕として得られた風化区分画像をもとに風化深度の違い を定量化して示した。

その手法は, 風化区分画像が示す風化深度とDN值の 関係を図ー13に示し，図ー11に示した屋代川縦断面図の 中のDN值のデー夕をもとに風化深度への換算を可能と した。その換算值は，風化殼の深度から経験的に求めた

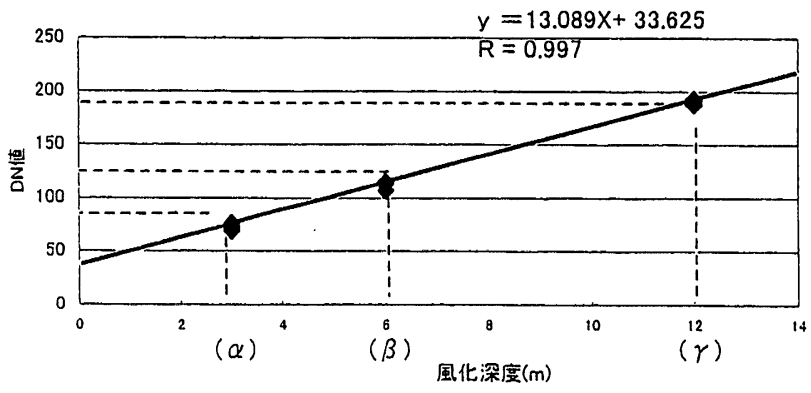

図一13 風化区分とDN值の相関性

Fig. 13 Correlation of weathering classification and DN value $\alpha=3 \mathrm{~m}, \beta=6 \mathrm{~m}, \gamma=12 \mathrm{~m}$ を基準值とし, 衛星データが 示すDN值に対応させたものである。

風化区分画像が示す 1 画素は，地上換算距離 $16 \mathrm{~m}$ 示

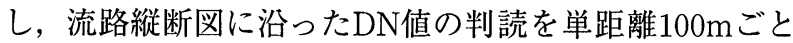
に計測し，下流端（No.1）から最上流端（No.26）まで の集計を求めた。ここに示す崩壊土砂量は，平均断面法 による体積土砂量（V) である。いま区間nにおける全 体積土砂量 $\mathrm{V}$ は, 式(3)により求められる。

$$
V=\int_{1}^{n} d V=\sum_{i=1}^{n} \frac{1}{2}\left(A_{i}+A_{i+1}\right) \cdot d \cdot
$$

ここに， $A_{i} ， A_{i+1} ;$ 区間 $\mathrm{i}$ および $\mathrm{i}+1$ 番目の断面皘 $\mathrm{d} ;$ 区間距離

その集計量は, 崩壊土砂量計算値として表ー 8 に示した。 （2）崩壊場所の予測

重回帰モデルとして作成した地盤主題図は，対象地域 である広島市佐伯区において 1 万分の 1 地形図との重ね 合わせによる地理情報デー夕を作成し，データベース化 した。そのデータを用いて, 崩壊場所の予測を検討した ${ }^{18)}$ 。

ここに用いた地盤主題図は，観測年（1997年）の地形 要因データであり，地盤データベースとしての利用が可 能である。これらのデー夕を用いて，1999年 6 月29日に 発生した土砂災害の危険箇所を予測するにあたり，ここ では多変量解析の中から判別分類を行うことを目的とす る数量化第 II 類を適用する。その解析範囲は，図ー10に 示した風化区分図の中から拡大範囲の領域（100画素 $\times$ 100画素）を対象とした。

まず外的基準を設定するにあたり，作成した地盤主題 図の中から土砂崩壊現象の発生に寄与すると考えられる デー夕を選定する。数量化第 II 類の処理結果から判別区 分されるデー夕は，外的基準として選定したカテゴリー を母集団とする分離度の良否によって示される。それは 
表- 8 崩壊土砂量計算表

Table 8 Amount of collapse of disaster

\begin{tabular}{|c|c|c|c|c|c|c|c|}
\hline $\begin{array}{l}\text { 測点 } \\
\text { No. }\end{array}$ & $\begin{array}{l}\text { 追加距 } \\
\text { 離(m) }\end{array}$ & DN 值 & $\begin{array}{c}\text { 風化層 } \\
(\mathrm{m})\end{array}$ & $\begin{array}{c}\text { 横 距離 } \\
\text { (m) }\end{array}$ & $\begin{array}{c}\text { 断面積 } \\
\left(\mathrm{m}^{2}\right)\end{array}$ & $\begin{array}{c}\text { 平均断面 } \\
\text { 䅹 }\left(\mathrm{m}^{2}\right)\end{array}$ & $\begin{array}{l}\text { 体積 } \\
\left(\mathrm{m}^{3}\right)\end{array}$ \\
\hline No.1 & 0 & 135 & 7.8 & 30.0 & 140.4 & 140.4 & 0 \\
\hline No.2 & 100 & 70 & 2.8 & 30.0 & 49.7 & 95.0 & 9500 \\
\hline No.3 & 200 & 62 & 2.2 & 20.0 & 26.7 & 38.2 & 3820 \\
\hline No.4 & 300 & 43 & 0.7 & 12.5 & 5.2 & 16.0 & 1600 \\
\hline No.5 & 400 & 56 & 1.8 & 10.0 & 10.6 & 7.9 & 790 \\
\hline No.6 & 500 & 57 & 1.8 & 12.5 & 13.8 & 12.2 & 1220 \\
\hline No.7 & 600 & 35 & 0.1 & 15.0 & 0.9 & 7.4 & 740 \\
\hline No.8 & 700 & 35 & 0.1 & 10.0 & 0.6 & 0.8 & 80 \\
\hline No.9 & 800 & 66 & 2.5 & 7.5 & 11.0 & 5.8 & 580 \\
\hline No. 10 & 900 & 52 & 1.4 & 7.5 & 6.2 & 8.6 & 860 \\
\hline No.11 & 1000 & 35 & 0.1 & 10.0 & 0.6 & 3.4 & 340 \\
\hline No.12 & 1100 & 35 & 0.1 & 10.0 & 0.6 & 0.6 & 60 \\
\hline No.13 & 1200 & 35 & 0.1 & 7.5 & 0.5 & 0.5 & 50 \\
\hline No. 14 & 1300 & 49 & 1.2 & 15.0 & 10.8 & 5.6 & 560 \\
\hline No. 15 & 1400 & 49 & 1.2 & 15.0 & 10.8 & 10.8 & 1080 \\
\hline No. 16 & 1500 & 49 & 1.2 & 10.0 & 7.2 & 9.0 & 900 \\
\hline No. 17 & 1600 & 57 & 1.8 & 12.5 & 13.2 & 10.2 & 1020 \\
\hline No. 18 & 1700 & 40 & 0.5 & 10.0 & 3.3 & 8.2 & 830 \\
\hline No. 19 & 1800 & 35 & 0.1 & 10.0 & 0.6 & 1.9 & 190 \\
\hline No.20 & 1900 & 47 & 1.0 & 12.5 & 7.5 & 4.1 & 410 \\
\hline No. 21 & 2000 & 53 & 1.5 & 10.0 & 8.8 & 8.1 & 810 \\
\hline No.22 & 2100 & 67 & 2.6 & 7.5 & 11.7 & 10.2 & 1020 \\
\hline No.23 & 2200 & 66 & 2.5 & 10.0 & 14.7 & 13.2 & 1320 \\
\hline No.24 & 2300 & 55 & 1.6 & 12.5 & 12.1 & 13.4 & 1340 \\
\hline No.25 & 2400 & 49 & 1.2 & 10.0 & 6.9 & 9.5 & 950 \\
\hline No. 26 & 2500 & 104 & 1.4 & 10.0 & 32.1 & 19.5 & 1950 \\
\hline 合計 & & 崩 壊 & 土 砂 & 計 算 & 値 $=32$ & $020 \mathrm{~m}^{3}$ & \\
\hline
\end{tabular}

表－9 数量化分析 II 類アイテム・カテゴリー表

Table 9 Item category table of quantification analysis II

\begin{tabular}{|c|c|c|c|}
\hline アイテム & カテゴリー & カテゴリ一数量 & 偏相関係数 \\
\hline 風化 & $\begin{array}{l}\alpha \\
\beta \\
\gamma\end{array}$ & （外的基準） & \\
\hline 表層地質 & $\begin{array}{c}\text { 深成岩 } \\
\text { 固結堆積物 } \\
\text { 未固結堆積物 }\end{array}$ & $\begin{array}{c}-0.1448 \\
0.0226 \\
0.0304\end{array}$ & 0.0717 \\
\hline 土地利用 & $\begin{array}{c}\text { 人工針葉樹林 } \\
\text { 天然広葉樹林 } \\
\text { 市街地 }\end{array}$ & $\begin{array}{c}-0.2341 \\
0.0123 \\
3.5132\end{array}$ & 0.5617 \\
\hline 傾斜 & $\begin{array}{c}0 \sim 15^{\circ} \\
15^{\circ} \sim 40^{\circ} \\
40^{\circ} \text { 以上 }\end{array}$ & $\begin{array}{c}-0.2001 \\
0.0855 \\
0.9181\end{array}$ & 0.3159 \\
\hline 飽和度 & $\begin{array}{l}\text { 低含水域 } \\
\text { 中含水域 } \\
\text { 高含水域 }\end{array}$ & $\begin{array}{l}0.3904 \\
0.0342 \\
0.5652\end{array}$ & 0.1739 \\
\hline 土壤 & $\begin{array}{c}\text { 乾燥褐色森林土 } \\
\text { 残積性未熟土 } \\
\text { 粗粒残積未熟土 }\end{array}$ & $\begin{array}{c}-0.1711 \\
0.0251 \\
0.0375\end{array}$ & 0.0688 \\
\hline 地形 & $\begin{array}{c}\text { 山地 } \\
\text { 台地·丘陵地 } \\
\text { 低地 }\end{array}$ & $\begin{array}{l}0.0509 \\
0.0753 \\
1.1281\end{array}$ & 0.2497 \\
\hline
\end{tabular}

アイテムの中から相関比としての高い值を示す要因デー 夕を選択することが必要条件となる ${ }^{19}$ 。ここではアイテ 么項目の中から風化区分の相関比 (0.8) を得た。従っ てその他のアイテムを要因データとする数量化分析を 行った。それらの数量化演算デー夕および処理結果を表 一 9 にまとめて示した。

設定した外的規準は，風化区分の指標に示した弱風化

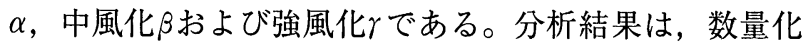
されたデータをスコア值分布図として図ー14に示した。

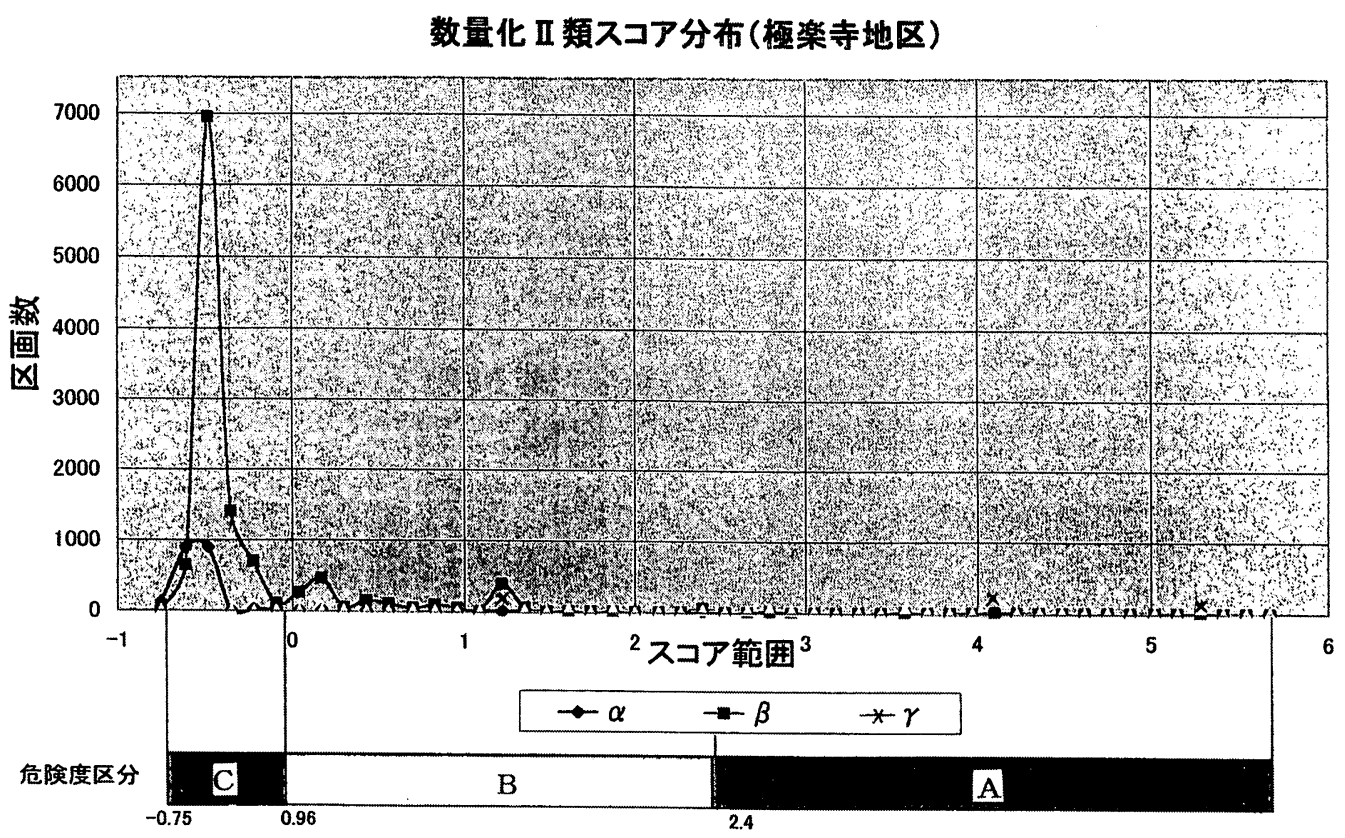

図一14 スコア分布図（風化度）

Fig. 14 Score distribution figure (degree of weathering) 


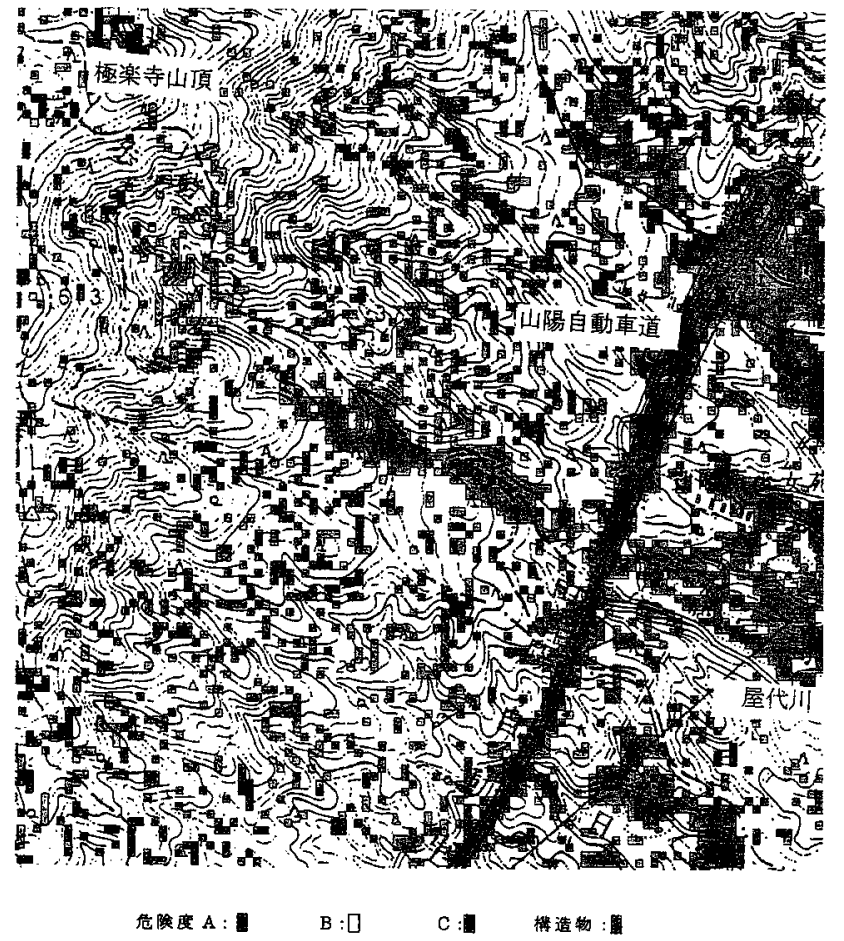

図-15 危険度評価図（外的基準：風化度）

Fig. 15 Danger evaluation figure (external standard: degree of weathering)

この地域にこれまで発生した土石流災害のうち，1987年 に発生した広島県北西部災害（加計町災害）の現地調查 にも見られたように，風化の進行した山腹に残積した風 化土および溪流に堆積した崩積土が移動現象を起こして いる201。このような地域特性をもとに，風化の進行した 強風化筒所に脆弱箇所を設定した。したがって，崩壊発 生箇所（ $\gamma$ 領域）を主として危険度Aとして表示し，更 にスコア值の区分数の分布から $\beta$ 領域を危険度Bとし， $\alpha$ 領域を危険度Cと設定した。この 3 区分を評価判定基準 として適用し，解析範囲（100画素×100画素）を対象に， 図一15に示す危険度評価図を作成した 211 。

\section{2 衛星データによる災害状況の予測結果}

人工衛星データから得られた空間情報データのうち, 作成した地盤主題図の利用により，ここでは炎害発生の 可能性を絞り込むための規模および場所の予測を検討し た。

崩壊発生規模の検討のため, 社地盤工学会調查部およ び中国支部による災害緊急調查委員会が2000年 3 月に提 出した調査報告書の中から，佐伯区管内の主な溪流にお ける発生土砂量を表-10に示す ${ }^{22 !}$ 。屋代川の場合，崩壊 後に発生土砂量として報告された $35,816 \mathrm{~m}^{3}$ と比較する と，風化度指標図をもとに得られた崩壊土砂量計算値 $32,020 \mathrm{~m}^{3}$ は，(発生量／計算量) $=1.12$ あ゙あ。広域性 を考虑すると，かなり良いと思われる值を得た。

土砂災害は，多くの要因が複数個以上作用して発生す ると考えられている。その中でも，渓流勾配，堆積土砂 抢よび多量の降雨が大きな要因を占めると考えられてい
表-10 佐伯区の流出土砂量

Table10 Amount of earth and sand outflow of Saekiward

\begin{tabular}{|c|c|c|}
\hline 渓流名 & 流域面溥 $\left(\mathrm{km}^{2}{ }^{2}\right)$ & 発生土秒量 $\left(\mathrm{n}^{3}{ }^{3}\right)$ \\
\hline 古野川 & 0.873 & 46,600 \\
\hline 堂名原支川 & 0.021 & 3,335 \\
\hline 兟 谷 川 & 3.705 & 111,308 \\
\hline 下ヶ迫川㳊川 & 0.195 & 8,161 \\
\hline 焦 代川 & 0.806 & 35,816 \\
\hline
\end{tabular}

る。ここでは，地域特性を考慮した風化区分デー夕をも とに堆積土砂量に着目した。強風化したまさ土の混在す る広島型花崗岩土は，土層内に浸透した雨水により傾斜 面を移動したと考えられる。その搪大現象が土石流とな り，下流への被害を大きくした。ここに検討した堆積土 砂は，時間経過の中で累積された土砂量である。従って この地域では溪流に堆皘する土砂量を地盤情報データと して捉え，追跡調查を行うことが必要であろう。そのた めにも今後, 衛星リモートセンシングによる堆積土砂量 の計測を継続することにより，流域における広域崩壊発 生規模の予測を可能にすると考えられる。

つぎに崩壊場所の予測は，崩壊発生より以前の人工衛 星デー夕を用いて検討した。ここでは広島豪雨災害時に 数ヶ所の崩壊を発生させた極楽寺山山腹を対象地として 取上げ，地盤主題図から崩壊危険度の高い箇所を検証推 定するものである。危険度判定のためのアイテム・カテ ゴリーは，外的基準として設定した風化区分との関係が 危険度評価に大きく関係していると考えられる。

危険度評価図は，相関比に基づく外的規準を風化度と して数量化第II類により作成したものである。土砂崩壊 の発生した屋代川流路に沿って危険度ランクを確認する と, 極楽寺山頂はランク $\mathrm{A}$ 評価され，その山頂を源頭 部とする土砂災害の発生流路では, ランクBの評価が多 くみられる。その流路に沿った崩壊的中率は，71.6\%で ある.このような評価図は, 潜在的な危険性を示すハザー ドマップになると考えられる。

1999年 6 月 29 日の集中豪雨と共に発生した斜面崩壊は, 風化した山地部と荒廃した土地利用および急傾斜地形に 関係すると考えられる。その山麓部に団地造成などの都 市化現象が拡大したことが，土砂移動現象に伴う土石流 の直撃や土砂流入などの被害を直接的に大きくしたと考 えられる。

\section{5.おわりに}

土石流の発生を予測するために，地球観測プラット フォーム技術衛星「みどり」のADEOS/AVNIRデータ を用い，地形要因デー夕を重回帰モデル画像として作成 した。そのデータをもとに，堆積土砂量の計測から堆皘 規模の予測を行った。更に，地盤主題図をもとに数量化 
第 II 類を適用し，崩壊の可能性の高い場所の予測を行っ た。ここに得られた結果を以下に要約する。

（1）空間情報データとして得られた人工衛星データは， 広域性，周期性，継続性などの特性を有すると共に， 観測時の地被地覆情報との相関性を示すディジタル データを提供する。

（2）重回帰モデルの説明変量として用いた比演算処理 データは，地被地覆データのうちの反射特性および放 射特性を特徵抽出データとする相関性を示し，それら のデータから地盤表層データの抽出が可能である。

（3）重回帰分析により得られた風化度の地盤情報デー夕 は，解析結果が示す重相関係数，F検定，t検定につ いて高い精度を示すと共に，有意性の高い最良回帰式 から重回帰モデルを作成することができた。

（4）土石流が発生した渓流の流域内には，風化残積土お よび崩積土が厚く堆積するが，この堆積土砂量は，ま さ土の風化特性を示す重回帰モデルと相関を示す。

（5）重回帰モデルとして作成した風化区分画像は，その ディジタル值が示す数值の判読から, 流出可能土砂量 としての堆積土砂量の推定が可能である。

（6）崩壊の予測は，時刻，場所および規模である。重回 帰モデルから推定された堆積土砂量は，実際の土砂崩 壊発生量と同等の值を示したことから，広域の風化土 地域において多発する崩壊予測箇所の絞达みおよび崩 壊予测規模の推定が可能である。

（7）地盤主題図として作成した重回帰モデルは，地形図 と共に地理情報データとしてのデータベース化が可能 であり，新規の広域情報として更新することが可能で ある。

（8）人工衛星デー夕をもとに作成した地盤主題図の中か ら，数量化第 II 類のアイテムとして設定した外的規準 は，土砂災害の可能性をランク付けした位置情報とし て，危険度ランクの画像表示が可能である。

（9）危険度ランクは，対象地域の平面情報として広域情 報を提供する。作成した評価図は，潜在的な危険度を 示すハザードマップになると考えられる。

\section{謝辞}

おわりに，本研究に使用したADEOS/AVNIRデータ は, 宇宙開発事業団から研究者用配布データとして提供 を受けたものである。ここに記して謝意を申し上げます。

\section{引用文献}

1）国土庁編（2000）；平成12年度防災白草，pp. 1-52

2 ) JOSシステム研究会編 (2003) ; 突然襲う土砂災害.

3）日本道路公団広島管理局編（1993）; 中国自動車道のり面防災 検討報告書，(財)高速道路技術センター，pp. 45-56.

4 ）島 重章（1994）; 重回帰分析による地盤判別分類画像の作成, (社)日本リモートセンシング学会第17回学術講演会, pp. 69 70.

5 ）島 重章, 田邉雅之, 吉國 洋（1998）；人工衛星デー夕を用 いた地盤データベースの作成，(社地盤工学会中国支部論文 集「地盤と建設」Vol.16, No.1，pp.7-14.

6 ）広島県企画部地域振興課編（1991）; 土地分類基本調査「広島」 解説担.

7 ）広島県企画部地域振興課編（1991）; 土地分類基本調查「広島」 倾斜区分図.

8 ）広島市消防局（1999）；平成11年 6 月降雨量デー夕，広島市佐 伯本部.

9 ）地盤工学会中国支部研究委員会編（2003）; まさ土地带の風化 及び降雨浸透特性と斜面に関する研究報告萻，第 1 章, pp. $1-15$

10）広島県土木建築部（2003）; 広島県土砂災害の状況，河川砂防 総室.

11）日本リモートセンシング研究会編（1998）；図解リモートセン シング，(社日本測量協会，pp. 26-55.

12）石井吉徳 (1981)；リモートセンシング読本, pp. 13-35，オー 厶社.

13）島 重章, 後藤恵之輔（1997）；重回帰分析による地盤分類主 題図の作成, 社日本写真測量学会誌, Vol. 36, No. 3, pp. 2933.

14）社地盤工学会編 (1995)；ジオテクノート「土は襲う」, pp. 81 88.

15）地盤工学会中国支部研究委員会編（2003）; まさ土地带の風化 及び降雨浸透特性と斜面に関する研究報告暃, 第 5 章, pp $181-189$.

16）石原慎一郎, 島 重章, 吉國 洋 (2002) ; リモートセンシン グによる土砂崩壊の予測, 広哥工業大学研究紀要, No. 36, pp. $91-98$.

17）島 重章，石原慎一郎（2003）; 地形要因デー夕を考虑した土 砂崩壊発生量の予測と評価, (社地盤工学会シンポジゥム No. 128 発表論文集, pp. 59-68.

18）島 重章, 吉國 洋, 神谷 誠, 小川洋一(1997) ; 衛星リモー トセンシングを利用した法面崩壊発生の予測について，社) 地盤工学会誌「土と基礎」Vol. 45, No.6, pp. 23-25.

19）林知已夫, 駒沢 勉 (1990) ; 数量化理論とデー夕処理, 朝倉 出版, pp. 49-52.

20）島 重章, 平本和則〈1995〉; 衛星デー夕を用いた広域崩壊地 の危険度評価，社)土質工学会中国支部論文集「地盤と建設」 Vol. 12 , No. 1, pp. 25-34.

21）島 重章, 石原慎一郎, 吉國 洋（2001）; 地形要因デー夕を 考慮した土砂崩壊発生の予測と評価，広島工業大学研究紀要, No. 35, pp. 95- 104 .

22）社地盤工学会・調查部，同・中国支部（2000）; 平成11年の広 島蒙雨災害調查報告葓「災害の概要」, pp. 4-33.

（原稿受付2003年 7 月 1 日，原稿受理2003年12月18日） 